\title{
Relationship Between Brand Jealousy And Conspicuous Consumption
}

\author{
Chairy $^{1}$, Jhanghiz Syahrivar ${ }^{2}$ \\ School of of Business, President University, 17750 Cikarang, Indonesia ${ }^{1}$ \\ Department of Marketing, Corvinus University of Budapest, 1093 Budapest, Hungary ${ }^{2}$ \\ chairy@ president.ac.id ${ }^{1}$,jhanghiz@ stud.uni-corvinus.hu²
}

\begin{abstract}
Brand Jealousy is one of the most important constructs in marketing yet it gains little attention from researchers. Previous research showed that this variable is the predictor of behavioral intention such as intention to buy a product. This research investigated whether brand jealousy affected conspicuous consumption. This research also found out the role of materialism in the relationship between brand jealousy and conspicuous consumption. Using regression analysis, this study revealed the positive and significant effect of brand jealousy on conspicuous consumption. On the other hand, moderation analysis showed that materialism did not moderate the relationship between brand jealousy and conspicuous consumption. The result of this research is expected to give a guideline for marketers in designing their marketing strategy.
\end{abstract}

Keywords: Brand jealousy, Conspicuous consumption, Materialism.

\section{Introduction}

The importance of branding as well as consumption has long been investigated. Researchers are interested to know the relationship between branding and consumption. They are keen to know whether branding aspects would predict consumer intention to buy a product. For instance, [1] investigated the effect of brand equity on repurchase intention in the hotel industry. [2] reported that brand's features and benefit, as well as relational aspects of brand perception, are major factors of consumers' attention. Consumer attitude towards a brand much relies on characteristics of a brand as well as consumers' experience on it. How consumers feel and evaluate a brand would affect their behavior toward a brand.

In consumer consumption context, recently there has been a great interest in investigating consumer buying intention by employing theories from consumer psychology literature and interpersonal relationship [3]. They showed the importance of brand love and jealousy in consumer behavior as well its role in creating consumer engagement. More specifically, they demonstrated the effect of brand jealousy on consumer buying intention and consumer engagement. Additionally, [4] showed that women consumers tend to consume conspicuously especially for luxury products because of mate guarding motive such as jealousy. In other words, there is a relationship between jealousy and conspicuous consumption.

Conspicuous consumption itself is affected by many factors. [5] investigated antecedents and consequences of materialism. They said that materialism has an important role during the global economic crisis. People with materialistic values have strong inclination towards goods which project wealth and status. To satisfy their desire, they may engage in risky financial behaviors which increase chances for economic crisis. They supported the existence of the 
dark side of materialism as reported before by [6] who showed some evidences regarding the impact of materialism (and overconsumption) on social and personal problems, among others are human exploitation, global poverty, environmental problems and reduced well-being and wellness. They also showed that materialism related to other negative consequences of consumption behavior, such as decreased life happiness, subjective well-being, life satisfaction, and environmental concerns. Their research model also showed that materialism has consequences on other shopping behaviors. They supported the findings of [7] who said that materialists tend to over-consume, thus, materialism leads consumers to overspending in shopping. Materialists also have positive attitude toward borrowing money which led them to easily purchasing non-essential items. The more consumers are materialistic, the more the tendency to engage in excessive shopping activities. It means that materialistic values will lead consumers to shop more than is necessary and we know that conspicuous consumption is a kind of overconsumption that aim to show others of what consumers have shopped.

This paper discusses the effect of brand jealousy on conspicuous consumption. Materialism as one of values will also be explored to reveal its role in enhancing the relationship between brand jealousy and conspicuous consumption. Using regression analysis, this paper discusses findings, research limitations, and recommendations for future research as well as developing marketing strategy by using brand jealousy construct.

\section{Literature Review}

\subsection{Brand Jealousy}

According to [3], jealousy is "arising from the potential, actual or imagined involvement of one's loved one or mate in a relationship with an interloper." Jealousy emerges as a defense mechanism in response to anticipated separation from one's loved. In consumer behavior context, consumers can have emotional attachment with a product or service.

[8] explained that consumers could fall in love with a brand or product. Therefore, it is predicted that consumers can be jealous when they see that a brand that they like has been purchased by others, and at present they do not have the brand due to some constraint. Brand jealousy thus occurs when a potential customer who has not yet purchased a specific brand perceives that another customer who already purchased a specific brand as a rival. On the other hand, unlike interpersonal relationships, brand jealousy does not have the reciprocity aspect and so do most brands.

[3] defined brand jealousy as "a complex of thoughts and feelings that follow threats to self-esteem generated by a romantically loved and esteemed brand in the mind of a romantic brand lover who does not possess the brand currently due to some constraint, after seeing another person (rival) using the same brand."

Brand jealousy has consequences on consumption behavior such as customer engagement and purchase intention [3], [9]. So far, there is only very limited research on brand jealousy and its consequences on consumer behavior. This research tries to fill this gap by investigating the effect of brand jealousy on conspicuous consumption.

2.2. Conspicuous Consumption

[10] was among the first to discuss conspicuous consumption which he defined as "The acquisition and display of expensive items to suggest wealth and/or attract attention to one's wealth." Conspicuous consumption is also known as a status consumption by which a person attempts to let others know his or her wealth by showing off his or her luxurious possessions. The product consumed is ranging from a small item like an expensive hand bag to a sport car.

How and why conspicuous consumption occurs attracts many researchers. Previous research showed that conspicuous consumption is triggered by many factors. Some 
researchers proposed the relative consumption effects which explained that consumers' satisfaction with their consumption depends on how much others are consuming. Other explanations are bandwagon effect (following others purchasing a product) and the snob effect (avoiding a popular good in order to be different with others) as signals of status, and thus as signals of conspicuous consumption. Reference group, education and materialism are reported to have been related to conspicuous consumption. Recently, the work of [4] showed that mate guarding motive which is triggered by jealousy lead women consumers to consume conspicuously especially for luxury products. In other words, brand jealousy can lead to conspicuous consumption.

H1: Brand Jealousy affects Conspicuous Consumption.

\subsection{Materialism}

Materialism occurs when consumers' attitudes as well as behaviors are driven by worldly possessions. The higher the materialistic value the higher the intention to pursue wealth and worldly possessions. [11] defined materialism as the manifestation of psychological traits which stresses on the importance consumers attach to possessions. Studies on materialism generally examine its individual and social consequences. According to Mason (1981), consumers with high materialistic values are more prone to shop excessively in order to enhance their social status. They may purchase expensive products in order to avoid losing social prestige [12]. Therefore, materialism is mostly perceived to be negative as it places wealth and worldly possessions integral to one's happiness [13]. Furthermore, [11] identifies three sub traits of materialism: possessiveness, non-generosity and envy. Possessiveness is the intention to maintain control and ownership of what one possesses. Non-generosity refers to unwillingness to release or share what one possesses with others. Envy is a feeling of discomfort at someone else's possessions which are deemed desirable.

This article investigated how materialism affect the relationship between brand jealousy and conspicuous consumption. It is predicted that the effect of brand jealousy on conspicuous consumption will be stronger for consumers who have higher level of materialism.

$\mathrm{H}$ 2: the effect of Brand Jealousy on Conspicuous Consumption is moderated by Materialism.

\section{Method}

This research investigated the influence of brand jealousy on conspicuous consumption. This quantitative study employed regression analysis to find out whether brand jealousy is a predictor of conspicuous consumption. This research also tried to reveal whether materialism is the moderator in the relationship between brand jealousy and conspicuous consumption.

Brand jealousy scale adopted the work of Sarkar and Sreejesh (2014) that consist of three item scales. Conspicuous consumption was measured by adopting the scale used by [14] which was developed by [15]. The level of materialism was measured by using Material Values Scale developed by [16], as used by [17]. This scale consists of 9-item short version form of Material Values Scale of [16].

The research model and variables operationalization are presented below: 


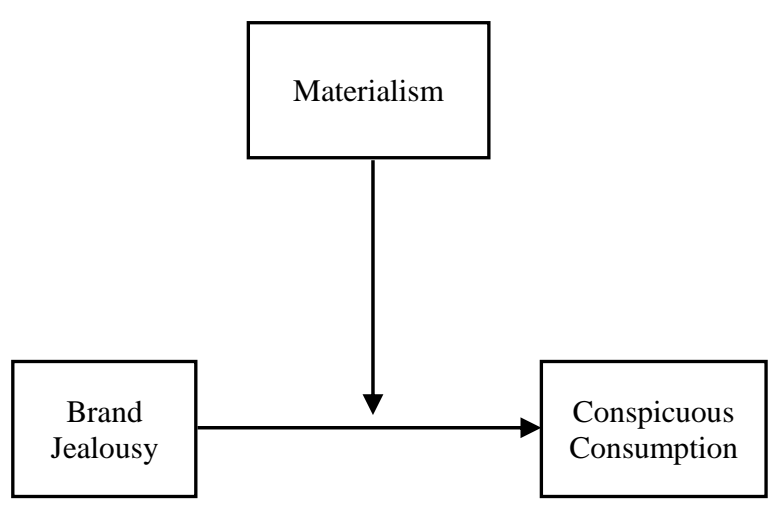

Fig. 1. Research Model

Table 1 below showed the definition and item used to measure the research variables. All variables were measured using the five point Likert Scale. Before running the regression analysis, these three scales were tried out using 30 samples from the same population. Reliability test has resulted in acceptable scores as follow: 0.798 for Brand Jealousy, 0.881 for Conspicuous Consumption, and 0.892 for Materialism.

Table 1. Operationalization of Variables

\begin{tabular}{l}
\hline Variables \\
Brand Jealousy \\
A complex of thoughts and are using the brand and I don't have it. \\
feelings that follow threats to 2 I feel very possessive about the brand scale \\
self-esteem generated by a when I see that others are using the brand \\
romantically loved and and I don't have it \\
esteemed brand in the mind 3 The thought that others are using the \\
of a romantic brand lover brand and I don't have it always haunts me \\
who does not possess the (Biçakcioğlu, et al., 2017). \\
brand currently due to some \\
constraint, after seeing \\
another person (rival) using \\
the same brand. (Sarkar \& \\
Sreejesh, 2014) Research
\end{tabular}




\begin{tabular}{|c|c|}
\hline $\begin{array}{l}\text { Conspicuous Consumption } \\
\text { Spending money on goods in } \\
\text { order to indicate wealth to } \\
\text { other members of the } \\
\text { society (Veblen, 1899; } \\
\text { Richins \& Dawson, 1992)) }\end{array}$ & $\begin{array}{l}\text { 1. Before purchasing a product, it is } 5 \text { point Likert scale } \\
\text { important to know what friends think of } \\
\text { different brands or products I am } \\
\text { considering. } \\
\text { 2. Before purchasing a certain product, it is } \\
\text { important to know what kinds of people buy } \\
\text { brands or products I am considering. } \\
\text { 3. Before purchasing a product, it is } \\
\text { important to know what others think of } \\
\text { people who use certain brands or products I } \\
\text { am considering. } \\
\text { 4. Before purchasing a product, it is } \\
\text { important to know what brands or products } \\
\text { to buy to make a good impression on others. } \\
\text { (Ismail, et al., 2018). }\end{array}$ \\
\hline $\begin{array}{l}\text { Materialism } \\
\text { The manifestation of } \\
\text { psychological traits, i.e. the } \\
\text { importance consumers } \\
\text { attach to possessions } \\
\text { (Belk, 1985; Richins, } \\
\text { 2004; Lipovčan, Prizmić- } \\
\text { Larsen \& Brkljačić, 2015) }\end{array}$ & $\begin{array}{l}\text { 1. My life would be better if I own certain } \\
\text { things I don't have. } \\
\text { 2. The things I own say a lot about how } \\
\text { well I'm doing. } \\
\text { 3. I'd be happier if I could afford to buy } \\
\text { more things. } \\
\text { 4. It bothers me that I can't afford to buy } \\
\text { things I'd like. } \\
\text { 5. Buying things gives me a lot of pleasure. } \\
\text { 6. I admire people who own expensive } \\
\text { homes, cars, clothes. } \\
\text { 7. I like to own things that impress people. } \\
\text { 8. I like a lot of luxury in my life. } \\
\text { 9. I try to keep my life simple, as far as } \\
\text { possessions are concerned. } \\
\text { (Segal \& Podoshen, 2013) }\end{array}$ \\
\hline
\end{tabular}

\section{Discussion}

The aim of this study is to investigate the effect of brand jealousy on conspicuous consumption (H1). This study also tried to reveal the role of materialism in the relationship between brand jealousy and conspicuous consumption (H2). Based on the data drawn from 200 students of Tarumanagara University, the research findings are presented in Table 2 below:

Table 2. The Research Findings

\begin{tabular}{|c|c|c|c|}
\hline Hypotheses & $\mathrm{t}$ value & Sig & Result \\
\hline $\begin{array}{l}\text { H1: Brand Jealousy } \rightarrow \\
\text { Conspicuous Consumption }\end{array}$ & 2.809 & .005 & Supported \\
\hline H2: Moderation Effect & -1.481 & .140 & Not Supported \\
\hline
\end{tabular}

As predicted, the first hypothesis is supported ( $\mathrm{t}$ value $=2.809 ; \mathrm{p}<0.05)$, indicating that students who have a high brand jealousy will have a stronger inclination to consume conspicuously. This finding supports the previous research which showed a positive effect of brand jealousy on conspicuous consumption [3], [4], [9]. 
On the other hand, the second hypothesis is not supported by data ( $\mathrm{t}$ value $=-1.481 ; \mathrm{p}$ > $0.05)$. This finding indicates that materialism does not moderate the effect of brand jealousy on conspicuous consumption. In other words, the effect of brand jealousy on conspicuous consumption will not be stronger or weaker when the materialism of consumer is high compare to when the materialism is low. Further, regression analysis showed that materialism directly affected conspicuous consumption. It means, the stronger the materialism score of students, the higher their inclination to consume conspicuously. Brand jealousy and materialism does not interact each other in affecting conspicuous consumption.

\section{Conclusion}

In today's competitive environment, marketers need to develop effective marketing strategies to gain more market share. By understanding consumer behavior, it will be easier for marketer to fulfill customer need and want. On marketer side, conspicuous consumption is one of consumer behavior that gain marketers' attention. By facilitating conspicuous consumption, marketer could get more sales revenue. The result of this research suggest that marketers need to arouse brand jealousy in order to generate more sales revenue through conspicuous consumption.

This research failed to show a moderation effect of materialism. The effect of brand jealousy on conspicuous consumption does not depend on how strong the materialism. On the other hand, materialism affected conspicuous consumption positively and significantly ( $\mathrm{t}$ value = 3.940; sig < 0.05). Both, brand jealousy and materialism affected conspicuous consumption significantly. To succeed, marketers need to pay attention on the role of either brand jealousy or materialism or both of them simultaneously to boost sales revenue.

This research showed a significant effect of brand jealousy on conspicuous consumption. On the other hand, the prediction that materialism will moderate the effect of brand jealousy on conspicuous consumption was not supported. To enhance the generalizability, further research should consider exploring non student populations. Considering the vital role of brand jealousy on generating sales revenue, further research should also heavily investigate the antecedents of brand jealousy. Considering the result of this research shows materialism is not a moderator in this model, it will be fruitful to investigate further whether materialism is the mediator in this model.

\section{References}

[1] A. Y. S. Lin, Y. T. Huang, Lin, and M.K., "Customer-based brand equity: The evidence from China," Contemp. Manag. Res., vol. 11, no. 1.

[2] N. Kervyn, S. T. Fiske, Malone, and C., "Brands as intentional agents framework: How perceived intentions and ability can map brand perception," J. Consum. Psychol., vol. 22, no. 2, pp. 166-176.

[3] A. Sarkar, Sreejesh, and S., "Examination of the roles played by brand love and jealousy in shaping customer engagement," J. Prod. Brand Manag., vol. 23, no. 1, pp. 24-32.

[4] Y. Wang, Griskevicius, and V., "Conspicuous consumption, relationships, and rivals: Women's luxury products as signals to other women. Journal of," Consum. Res., vol. 40, no. 5, pp. 834-854.

[5] S. Segev, A. Shoham, Gavish, and Y., "A closer look into the materialism construct: the antecedents and consequences of materialism and its three facets," J. Consum. Mark., vol. 32, no. 2, pp. 85-98.

[6] S. Alexander, Ussher, and S., "The voluntary simplicity movement: A multi-national 
survey analysis in theoretical context," J. Consum. Cult., vol. 12, no. 1, pp. 66-86.

[7] R. E. Goldsmith, L. R. Flynn, Clark, and R.A., "Materialism and brand engagement as shopping motivations," J. Retail. Consum. Serv., vol. 18, no. 4, pp. 278-284.

[8] R. Batra, A. Ahuvia, and R. P. Bagozzi, "Brand Love," J. Mark., vol. 76, pp. 1-16.

[9] S. Sreejesh, "Consumers' perceived brand aspiration and its impact on intention to pay price premium: Moderating role of brand jealousy," Theor. Econ. Lett., vol. 5, no. 2, p. 273.

[10] T. Veblen, The theory of the leisure class. New Brunswick, NJ: Transaction Publishers.

[11] R. W. Belk, "Materialism: Trait aspects of living in the material world," J. Consum. Res., vol. 12, no. 3, pp. 265-280.

[12] J. Liao, Wang, and L., "Face as a mediator of the relationship between material value and brand consciousness," Psychol. Mark., vol. 26, no. 11, pp. 987-1001.

[13] J. S. Podoshen, Andrzejewski, and S.A., "An examination of the relationships between materialism, conspicuous consumption, impulse buying, and brand loyalty," J. Mark. Theory Pract., vol. 20, no. 3, pp. 319-334.

[14] E. Chung, Fischer, and E., "When conspicuous consumption becomes inconspicuous: the case of the migrant Hong Kong consumers," J. Consum. Mark., vol. 18, no. 6, pp. 474-487.

[15] M. L. Richins, K. K. R. McKeage, and and Debbie Najjar, “,'An Exploration of Materialism and Consumption-Related Affect,", in NA - Advances in Consumer Research Volume, vol. 19, J. John F. Sherry and B. Sternthal, Eds. Provo, UT: Association for Consumer Research, Pages, pp. 229-236.

[16] M. L. Richins, "The material values scale: Measurement properties and development of a short form,” J. Consum. Res., vol. 31, no. 1, pp. 209-219.

[17] L. K. Lipovčan, Z. Prizmić-Larsen, Brkljačić, and T., "Materialism, affective states, and life satisfaction: case of Croatia," Springerplus, vol. 4, no. 1, p. 699. 